\title{
The American Association for Thoracic Surgery John W. Kirklin Research Scholarship, 2006-2008
}

\section{STIPEND \$75,000 PER YEAR}

$\mathrm{T}$ The American Association for Thoracic Surgery announces the AATS John W. Kirklin Research Scholarship to provide an opportunity for research, training, and experience for a North American surgeon committed to pursuing an academic career in cardiothoracic surgery. The scholarship will be funded by the Association and administered by the Graham Education and Research Foundation.

The research program must be undertaken within the first three years after completion of an approved cardiothoracic residency. Applications for the scholarship may be submitted during the candidate's final year of cardiothoracic residency or during his or her first two years in an academic position. The duration of the scholarship is to be two years.

The yearly stipend shall be $\$ 75,000$ paid to the host institution. In addition, a grant of $\$ 5,000$ per year shall be made for support of research supplies, travel, and other legitimate academic expenses of the scholar. Applications for the scholarship are available from the Secretary of The American Association for Thoracic Surgery. The application will consist of three components:

1. The candidate must submit a proposal for the research to be undertaken and a statement of career plans and how the research activity will relate to the candidate's academic career.

2. The Director of the laboratory in the institution at which the research will be performed shall submit an endorsement of the proposal and indicate the facilities and degree of support available for the candidate's research.
3. The Chair of the candidate's department shall submit his or her endorsement of the proposal and indicate the willingness of the institution to provide an academic appointment for the candidate upon completion of the scholarship.

The application and its three components shall be submitted to the Secretary of The American Association for Thoracic Surgery by July 1, 2005. Announcement of the award will be made by the President of The American Association for Thoracic Surgery by December 15, 2005. The Scholarship will begin July 1, 2006. Following completion of the two-year program the scholar shall submit a written report of his/her research activities to the membership of the Association.

Applications for the scholarship are available from:

Irving L. Kron, MD, Secretary

The American Association for Thoracic Surgery

900 Cummings Center

Suite 221-U

Beverly, MA 01915

978-927-8330: fax 978-524-0461

Applications may be downloaded from the AATS Web site at: http://www.aats.org/research/grants.

\section{The American Association for Thoracic Surgery Research Scholars}

Edward D. Churchill, Research Scholar

Alfred Blalock Research Scholar

John H. Gibbon, Jr. Research Scholar

Alton Ochsner Research Scholar

Robert E. Gross Research Scholars

John Alexander Research Scholar

1996-1998

Andrew G. Morrow Research Scholar

Dwight Harken Research Scholar
1992-1994

1994-1996

1997-1999

1986-1988

1988-1990

1990-1992

1998-2000
Mark K. Ferguson, MD

University of Chicago

Gus J. Vlahakes, MD

Massachusetts General Hospital

Donald D. Glower, MD

Duke University Medical Center

David H. Adams, MD

Brigham and Women's Hospital

Mehmet C. Oz, MD

Columbia-Presbyterian Medical Center

Thoralf Mauritz Sundt III, MD

Washington University School of Medicine

Richard Norris Pierson III, MD

Vanderbilt University Medical Center

Stephen C. Yang, MD

Johns Hopkins University School of Medicine

Bruce Rosengard, MD

University of Pennsylvania 
Second Edward D. Churchill Research Scholar

Second Alfred Blalock Research Scholars

Second John H. Gibbon, Jr. Research Scholars

Second Alton Ochsner Research Scholars

Second Robert E. Gross Research Scholars

Second John Alexander Research Scholar

Second Andrew G. Morrow Research Scholars
2002-2004

2003-2005

2004-2006

2005-2007
Joseph B. Shrager, MD

University of Pennsylvania School of Medicine

Abbas Ardehali, MD

UCLA School of Medicine

Thomas K. Waddell, MD

University of Toronto/Toronto General Hospital

Richard J. Battafarano, MD

Washington University School of Medicine

Carmelo A. Milano, MD

Duke University Medical Center

Yolonda L. Colson, MD

Brigham \& Women's Hospital

Michael S. Mulligan, MD

University of Washington

Ross H. Bremner, MD

University of Southern California Keck School of Medicine

Vivek Rao, MD

Toronto General Hospital

King F. Kwong, MD

University of Maryland School of Medicine

Marc de Perrot, MD, MSc

Toronto General Hospital/University of Toronto

Frederick Y. Chen, MD, PhD

Brigham and Women's Hospital 